\title{
Influence of the geometry of units and filling of vertical joints in the compressive and tensile strength of masonry
}

\author{
Vladimir G. Haach ${ }^{1, a}$, Graça Vasconcelos ${ }^{1, b}$ and Paulo B. Lourenço ${ }^{1, c}$ \\ ${ }^{1}$ ISISE, Department of Civil Engineering, University of Minho, Campus de Azurém, 4800 - \\ Guimarães, PORTUGAL, Phone number: (+351) - 253510200, Fax number: ( 351) - 253510217

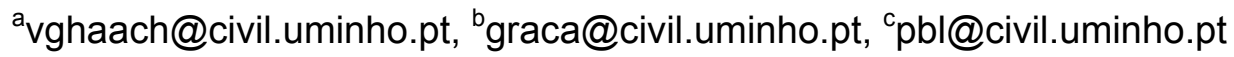

Keywords: concrete block masonry, compressive strength, tensile strength, mortar joints.

\begin{abstract}
In the present paper, a focus is given to the mechanical properties of masonry related to compressive and tensile strength of concrete block masonry as these properties are important parameters to the analysis of the lateral behavior of masonry walls, determining its lateral resistance and ductility. These properties play also a central role when analytical and numerical analysis is required. The influence of two parameters on the mechanical properties of masonry was analyzed, namely the geometry of the units and the filling of the vertical joint. Results showed that masonry under compression behaves as an homogeneous material and the stress-strain diagrams can be represented by a parabola similarly to what is suggested to structural concrete. In case of tensile strength, the filling of vertical joints appears to influence considerably the tensile strength. The filling of the vertical joints increased the strength and leads to a more brittle behaviour.
\end{abstract}

\section{Introduction}

Masonry is one of the most antique structural systems in the world and is present on the most impressive historical buildings. However, it lost prestige during the XX century with the advance of other structural systems such as reinforced concrete and steel in all world and in partcular in Portugal, where almost no modern structural masonry exist. This scenery is, to certain extent, the result of scarce or even absence of rules, recommendations and design methods available for masonry. On the other hand, masonry has advantages other than good performance as structural system, such as durability, fire resistance and thermal and acoustic insulation. Another advantage of masonry is the easiness of construction. It can be considered as a precast structure resulting from the assemblage of prefabricated masonry units (blocks and bricks,) and pre-mixed mortar if additional precast slabs are applied, promoting a clean work place. The masonry materials are relatively cheap and durable and can provide great flexibility in the plan of the structure and can additionally offer an attractive external appearance [1].

Differently of other industries, civil construction does not allow mass production which hinders the organization and control of work. In general, limited qualifications of workers added to the acceptance of unfeasible periods of construction lead to a very flexible system with low level of quality. Therefore, the rationalization of the masonry construction process through simplification of tasks, the optimization of the construction technology by offering innovative construction systems and improvement of quality control provide a better performance of the built environment and makes masonry an effective and alternative structural solution [2]. In this scope, the study of different geometries for masonry units and new methods for assemblage of masonry units, namely by the use of dry stack vertical joints can lead to more rational constructictive systems. According to [3] dry-stack systems can be built with lower skilled labor, which can be a real advantage in a scenery of reduced or inexistent trained masons. Drystacking also increases productivity and speed of construction, leading to clear economical advantages.

Thus, following the conception of two innovative constructive systems in concrete block masonry, an experimental study is presented in this paper aiming at evaluating and comparing the 
mechanical peformance of two distinct masonry bonds under compressive and tensile loading. One masonry bond represents the traditional two hollow cell concrete masonry with filled vertical joints and the another one consists of three hollow cell masonry with dry vertical joints. The results of a set of uniaxial compressive tests carried out in the parallel and perpendicular direction to the bed joints and of a set of diagonal compressive tests in both masonry bonds are presented and discussed.

\section{Experimental Program}

The experimental program was carried out at Laboratory of Structures of University of Minho (LEST) aiming at evaluating the influence of different masonry bonds, mainly as concern the geometry of masonry units and type of vertical joints, on the compressive and tensile behavior of masonry.

Properties of materials. Masonry wallets were built with three and two hollow cell concrete blocks, whose shape and geometry are shown in Fig. 1. Due to laboratory limitations, half scale concrete blocks were produced. The maximum size of the aggregates had to be reduced to account for the reduced scale of the blocks. As information on the compressive strength on concrete blocks in the direction parallel to bed joints is needed due to the behavior of masonry beams under flexure, compressive tests were performed in two perpendicular directions, namely in parallel direction to the holes and in the perpendicular direction to the webs according to [4]. The average values obtained for the compressive strength perpendicular to the webs were $7.6 \mathrm{MPa}$ and $6.5 \mathrm{MPa}$ for three and two hollow cell concrete blocks respectively. On the other hand, the average values obtained for the compressive strength and elastic modulus in the direction parallel to vertical holes were 12.1 MPa and $9.6 \mathrm{GPa}$ and, $9.4 \mathrm{MPa}$ and $8.9 \mathrm{GPa}$ for three and two hollow cell concrete blocks respectively. Modified general purpose mortar with a binder/aggregate ratio of 1:3 (cement:sand) was used in the construction of the masonry in order to achieve a compressive strength of mortar of about $10 \mathrm{MPa}$, which is a recommend value for masonry structures located in seismic areas [5], and so that appropriate consistence enables the filling of the reinforced central hollow cell of the concrete units in case of reinforced masonry [6]. Three specimens of mortar were taken during the construction of the masonry wallets and tested according to [7].

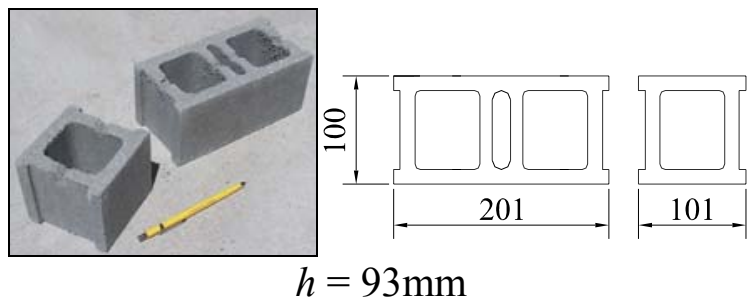

(a)

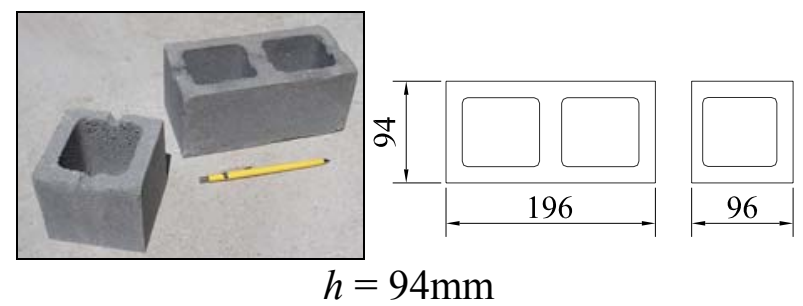

(b)

Fig. 1 - Geometry and shape of the units; (a) three cell blocks (3C-units); (b) two cell blocks (2C-units). Dimensions are in $\mathrm{mm}$.

Masonry wallets, procedures and instrumentation. Masonry wallets to be tested were built following the two running masonry bonds previously defined: two hollow cell concrete blolks with filled verical joints and three hollow cell concrete blocks with dry stacked vertical joints. Masonry joints of approximately $8 \mathrm{~mm}$ were considered to account for the reduced scale of the masonry units. Six masonry wallets were built for the uniaxial and diagonal compressive tests with the geometry indicated in Fig. 2 for both masonry bonds. The monotonic uniaxial and diagonal compressive tests were carried out under displacement control at a rate of $5 \mu \mathrm{m} / \mathrm{s}$ by means of an external LVDT connected to the actuator according to the european normalization $[8,9]$. The masonry wallets were cured at the laboratory environment with a relative air humidity of approximately $80 \%$. In order to ensure proper curing of the specimens, the tests were carried out after 28 days after the 
construction. The deformations of the specimens were measured by the set of LVDTs placed according to the configuratioon indicated in Fig. 2.

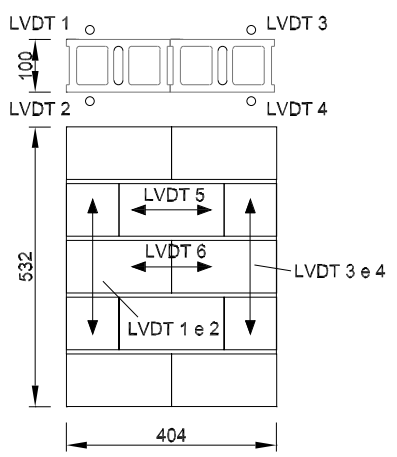

(a)

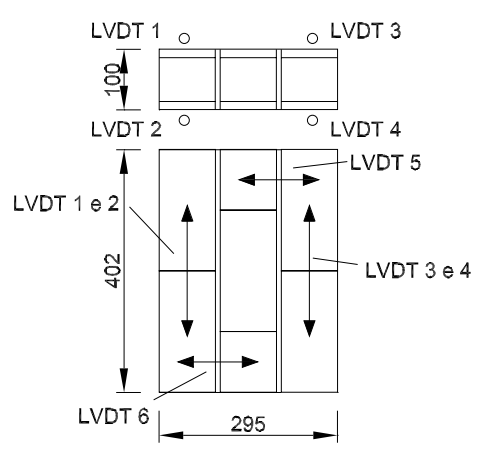

(b)

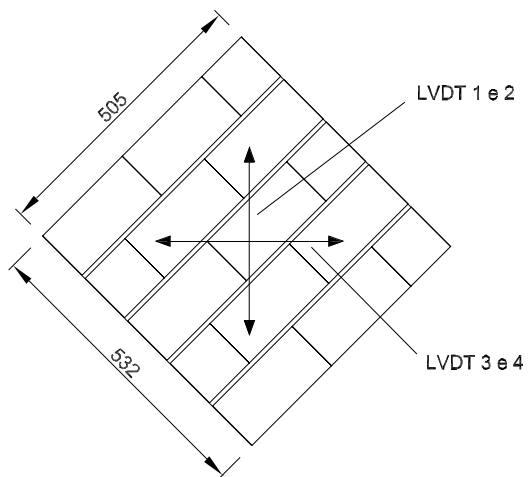

(c)

Fig. 2 - Geometry of the masonry wallet; (a) compression perpendicular to bed joints; (b) compression parallel to bed joints ; (c) diagonal compression. Dimensions are im mm.

\section{Results}

Compression perpendicular to bed joints. The compressive behavior of concrete block masonry was very similar for both masonry bonds under analysis. The crack pattern is in a great majority composed by vertical cracks through vertical joints and concrete blocks, which results from the development of tensile stresses in the perpendicular direction of the applied load, see Fig. 3a. The onset of cracking takes place at vertical joint in the middle height of specimen and propagates to the upper and bottom concrete units, when their tensile strength is achieved.
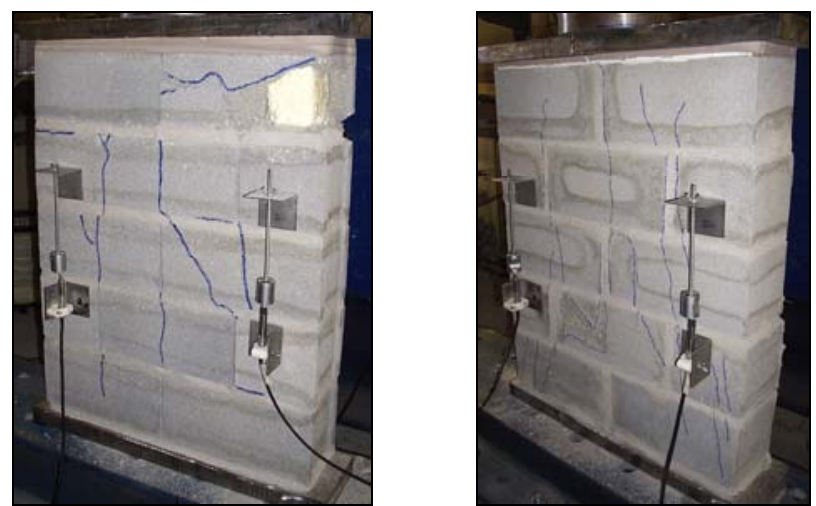

(a)

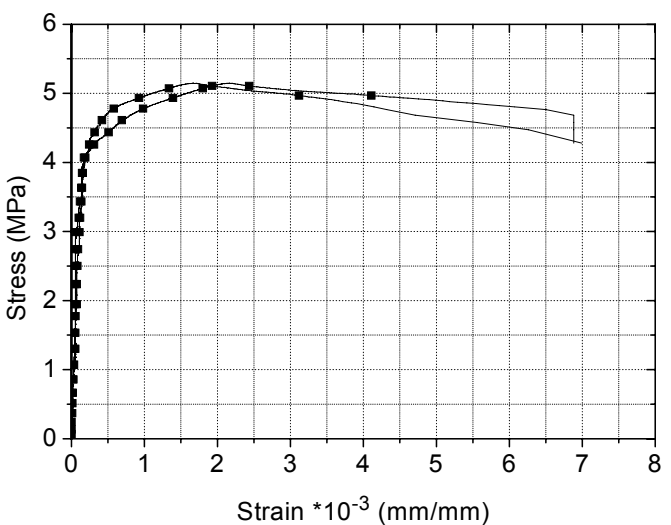

(b)

Fig. 3 - Experimental results for compression normal to bed joints; (a) crack patterns of specimens; (b) horizontal strains of specimens

The main difference on the behaviour of dry stacked masonry and common running masonry with filled vertical joints is the more gradual and higher cracking in case of filled vertical joints. However, both masonry bonds exhibited a very brittle behaviour, which is confirmed by the typical stress-strain diagrams shown in Fig. 4. LVDTs 5 and 6 were used to compare the horizontal displacements at the middle of a unit and at the level of vertical joints. It is observed that no differences were observed between those deformations, confirming the homogeneous behaviour of the masonry specimens, see Fig. $3 \mathrm{~b}$. The average values obtained for the compressive strength in the direction perpendicular to bed joints and elastic modulus were $6.0 \mathrm{MPa}$ and $10.5 \mathrm{GPa}$ for dry stacked masonry and of $5.4 \mathrm{MPa}$ and $10.5 \mathrm{GPa}$ for masonry with two cell concrete blocks and filled vertical joints, which stresses the similar response of the distinct bonds. A comparison between experimental results and the analytical parabolic relation between stress and strain of plan concrete 
suggested by [10] shows a good agreement with the experimental results on masonry and the standard funtion describing the uniaxial compression of concrete, see Fig. 4.

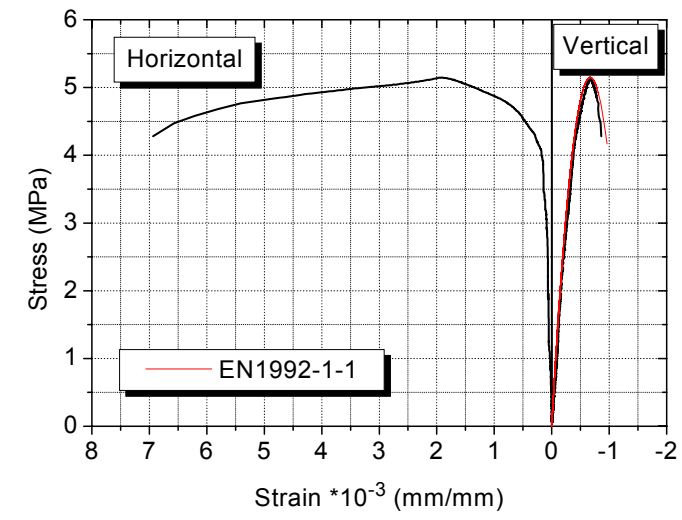

(a)

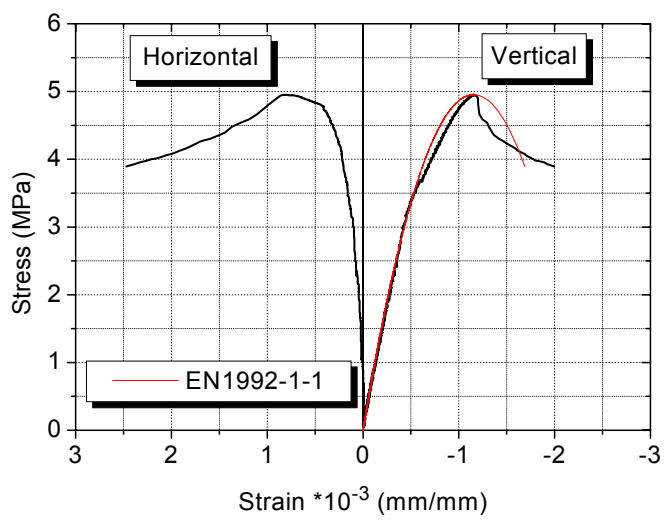

(b)

Fig. 4 - Common diagrams stress-strain of specimens in compressive tests normal to bed face: (a) 3C-units and (b) 2C-units.

Compression parallel to bed joints. The behavior of concrete block masonry under uniaxial compressive loading in the direction parallel to bed joints can be divided in two phases, see Fig. 5a. In a first phase, the compressive loading path goes essentially through the shells of the concrete units. Due to the Poisson's effect in the out-of-plane direction, the webs of the units are submitted to tensile stresses. When the tensile stresses reach the tensile strength of the concrete, the webs crack and the specimens are divided in two almost separated parts. In the first phase, tensile stresses also appeared in direction normal to bed joints which generated cracking in interface between unit and mortar resulting from the in-plane tensile stresses.

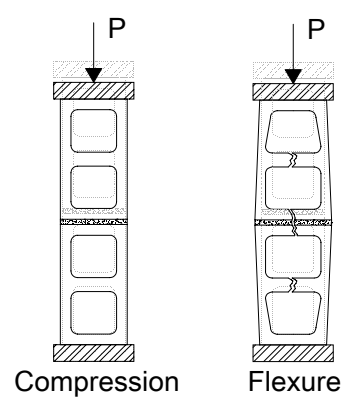

(a)

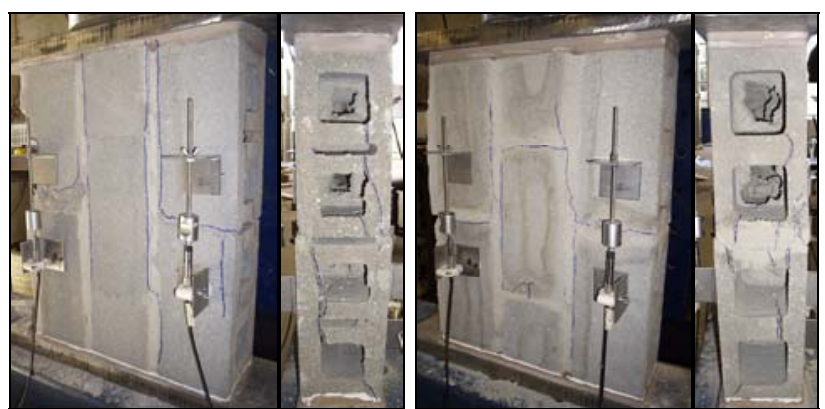

(b)

Fig. 5 - Behaviour of masonry under compression parallel to bedjoints. Cracked specimens of compressive tests parallel to bed joints.

The second phase concerns the flexural behaviour of the cracked parts of the wallet resulting from the load's eccentricity in relation to shells of the units, after which cracks along head joints and through units, following the direction of head joint develop, see Fig. $5 \mathrm{~b}$.

Compressive resistance of concrete block masonry is considerable lower when axial load is applied in the direction parallel to the bed joints, especially in case of masonry built with three cell concrete units and unfilled vertical joints. Nevertheless, much higher ductile behaviour, associated to ultimate strains higher than $10 \%$., characterizes the response of masonry wallets when loaded in the parallel direction to bed joints, see Fig. 6. The average values otained for the compressive strength parallel to bed joints and elastic modulus were $2.8 \mathrm{MPa}$ and $2.5 \mathrm{GPa}$ for three hollow cell concrete blocks and of 3.4MPa and 7.3GPa for two hollow cell concrete blocks and filled vertical joints. Additionally, some differences were detected in the shape of the stress-strain digrams for the distinct masonry bonds. The traditional running masonry bond with filled vertical joints and two cell concrete blocks exhibited gradual loss of stiffness and compressive resisance after the maximum load. On the other hand, the masonry composed by three hollow cell blocks and unfilled 
vertical joints appears to reach a stabilized decreasing stifness at peak stress, after which an considerable increase on the stifness anf loading resistance occurs, see Fig. 6b. This behavior seems to be related to the dry contacts at the level of dry vertical joints, leading to an increase on the compressive strength and stifness up to the failure of the webs by tensile stresses or up to the crushing of the frogged ends.

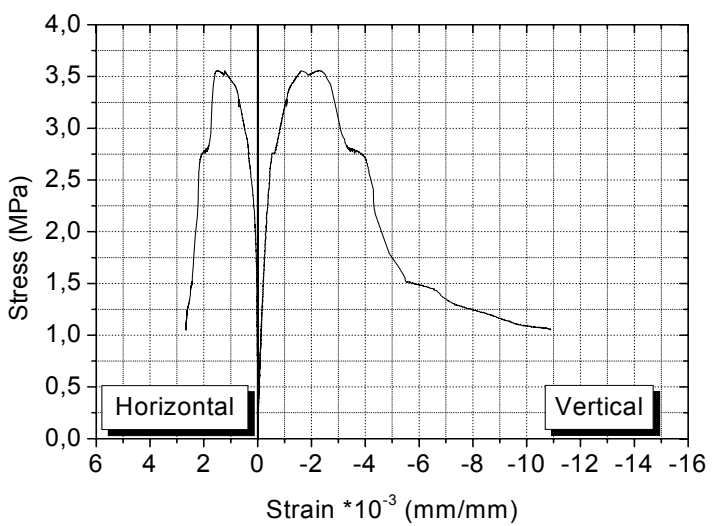

(a)

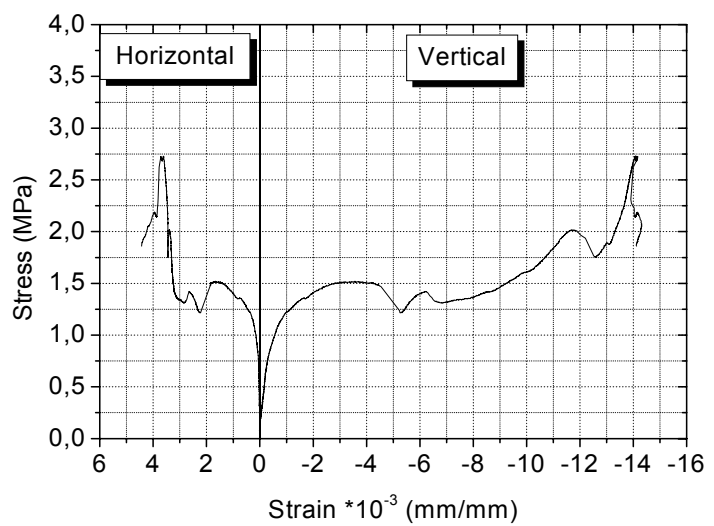

(b)

Fig. 6 - Typical stress- strain diagrams to compression paralle to bed joints: (a) 2C-units and (b) 3C-units.

Diagonal compression. The diagonal compression test allows obtaining the shear strength of the masonry through compressive loading, which generates an indirect tension in the perpendicular direction. Shear strength is calculated in a direct manner by dividing the applied force by the transversal area of the central section of the specimen, see Eq. (1). Results of LVDTs provide the distortion, see Eq. (2), from which the transversal elastic modulus is derived through Eq. (3).

$$
\begin{aligned}
& f_{t}=\frac{0,707 P}{\left(\frac{b+h}{2}\right) t} . \\
& \gamma=\frac{\Delta V+\Delta H}{l_{0}} . \\
& G_{t}=\frac{f_{t}}{\gamma} .
\end{aligned}
$$

In the equations, $f_{t}$ is the shear strength of the masonry, $P$ is the applied force, $b$ is the length of specimen, $h$ is the height of specimen, $t$ is the width of specimen, $\gamma$ is the distortion of the masonry, $\Delta V$ and $\Delta H$ are the vertical and horizontal shortening respectively, $l_{0}$ is the gage length and $G_{t}$ is the transversal elastic modulus of the masonry. The average values obtained for the tensile strength and transversal modulus were of $0.2 \mathrm{MPa}$ and $1.9 \mathrm{GPa}$ for the masonry built with three hollow cell units and dry vertical joints and of $0.6 \mathrm{MPa}$ and $2.2 \mathrm{GPa}$ for for the traditional running masonry with filled vertical joints. Presence of mortar in head joints seems to influence the shear strength leading to an increasing of about $300 \%$. The filling of vertical joints generated a better distribution of stresses since mortar increase the contact area. Besides, the filling of the vertical joints affected in a lower extent the stiffness of masonry with an increase of $20 \%$. For both geometries of units, only one crack appeared in specimensn along the unit-mortar interface indicating that the units had a tensile strength higher than the capacity of the unit-mortar interface, see Fig. 7. Failure of the specimens built with $2 \mathrm{C}$-units was very brittle with sudden cracking. On the other hand, the specimens built with 3C-units exhibited a very ductile behaviour. Even if the cracking visible to naked eye occurred suddenly as in case of specimens built with $2 \mathrm{C}$-units, after the achievement of the the maximum load there was a progressive loading decrease of about $20 \%$, after which load stabilization was followed by increasing deformation until the collapse. 


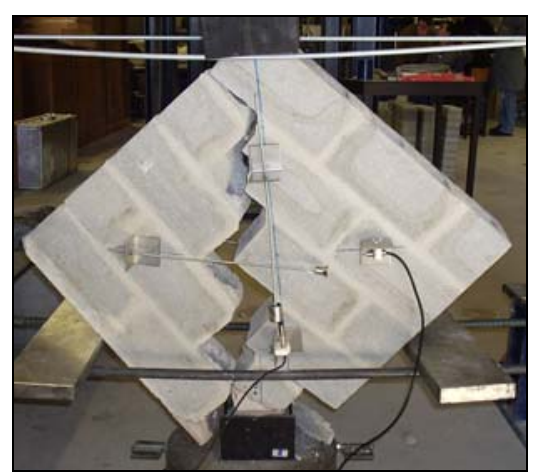

(a)

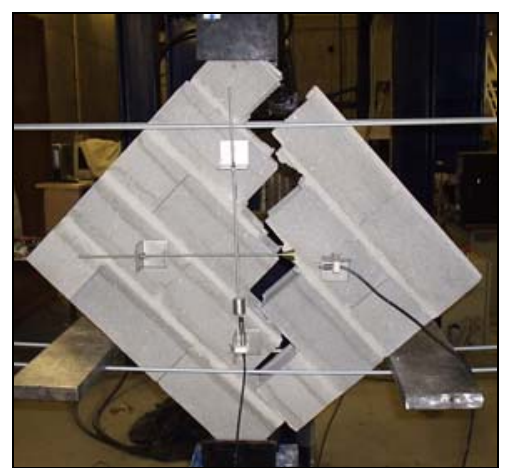

(b)

Fig. 7 - Typical crack patterns for diagonal compresson; (a) 2C-units and (b) 3C-units.

\section{Summary}

From the experimental campaign carried out on concrete block masonry with different types of concrete blocks and with filled and unfilled vertical joints, the following conclusions are drawn: (a) masonry under compression perpendicular to bed joints behaved as an homogeneous material and the experimental stress-strain diagram is well described by the analytical formulation suggested for concrete; (b) in case of compressive tests parallel to bed joints the failure mode and resisting mechanism was affected by the masonry bond, being the specimens with three hollow cell blocks and vertical dry joints less resistant and much more ductile; (c) an increase of the tensile strength with the filling of the vertical joints was obtained in diagonal compressive tests, even if a more brittle behavior was found in relation to specimens with three hollow cell units.. To sum up, it should be stressed that both masonry bonds exhibited a reasonable behavior, meaning that the simplification on the construction technology by using dry vertical joints is a real possibility.

\section{Acknowledgements}

The first author was supported by the Programme Alßan, the European Union Programme of High Level Scholarships for Latin America, Scholarship no E06D100148BR.

\section{References}

[1] A.W. Hendry: Structural Masonry, MacMillan Press LTDA, London, UK, 1998.

[2] F.K. Rauber: Contribuições Ao Projeto Arquitetônico De Edifícios Em Alvenaria Estrutural, Msc. Thesis, University Federal of Santa Maria, Rio Grande do Sul, Brazil, 2005, 111pp.

[3] C. Beall: New masonry products and materials, Progress in Structural Engineering and Materials, 2(3), 2000, 296-303.

[4] EUROPEAN STANDARD. EN 772-1, Methods of tests for masonry units - Part1: Determination of compressive strength. 2000.

[5] EUROPEAN STANDARD. EN 1996-1-1, Eurocode 6 - Design of masonry structures - Part11: General rules for reinforced and unreinforced masonry structures. 2005.

[6] Haach, V.G.; Vasconcelos, G.; Lourenço, P. B.; Mohamad, G. "Study of a mortar to use as infill and embedding", Proceedings of 10th North American Masonry Conference, St. Louis, Missouri, USA, 2007, 530-541.

[7] EUROPEAN STANDARD. EN 1015-11, Methods of tests for mortar for masonry - Part 11: Determination of flexure and compressive compressive strength of hardened mortar. 1999.

[8] EUROPEAN STANDARD. EN 1052-1, Methods of test for masonry - Part1: Determination of compressive strength. 1999.

[9] ASTM E519-02: Standard Test Method for Diagonal Tension (Shear) in Masonry Assemblages, 2000

[10] EUROPEAN STANDARD. EN 1992-1-1, Eurocode 2. Design of concrete structures. General rules and rules for buildings, 2004. 